\title{
Pensononowoor
}

2018, vol. 80, 101-111

http://dx.doi.org/10.12657/denbio.080.010

\author{
Monika Litkowiec (D), Andrzej Lewandowski (D) Jarosław Burczyk*
}

\section{Genetic status of Polish larch (Larix decidua subsp. polonica (Racib. Domin)) from Chełmowa Mountain: implications for gene conservation}

\author{
Received: 31 October 2018; Accepted: 4 December 2018
}

\begin{abstract}
The Polish larch (Larix decidua subsp. polonica (Racib. Domin), a subspecies of European larch, is one of the most valuable forest-forming trees in Poland. It was first discovered on the Chełmowa Mountain where Natural Reserve has been established to protect this subspecies. Currently, this unique population is at risk of extinction. Nonetheless, the knowledge on the genetic diversity of this population and surrounding larch forests is insufficient to undertake actions aimed at conservation of genetic resources. In this study, we examined the level of genetic diversity and differentiation of four subpopulations of Polish larch from Nature Reserve on the Chełmowa Mountain and surrounding areas.

We used eleven nuclear microsatellite markers (SSRs) combined in two multiplex PCR reactions. In total, 344 individuals of Polish larch were genotyped and subjected to further population genetic analyses.

We found the high level of genetic diversity (average: $H_{\mathrm{e}}=0.752, H_{\mathrm{o}}=0.720$ ) and low levels of genetic differentiation (average: $F_{\text {st }}=0.022$ ). The effective population size was large and homogeneous across subpopulations (mean $N_{\mathrm{e}}=90.7$ ), and we found no sign of inbreeding. The spatial genetic structure was detected in two older subpopulations but not in the younger one, suggesting its artificial origin. The old larch subpopulations were genetically homogeneous and they were related to the ancestral group of Polish lowland populations.

The old larch core populations growing on Chełmowa Mountain are relatively homogeneous and they well represent the ancestral genetic group of Polish lowland larch populations. However, they still exhibit relatively high genetic diversity and sufficiently large effective population sizes assuring their adaptive potential for a long-term existence. Surrounding larch populations are even more genetically diverse but this might be the effect of an admixture of seed sources from various populations from a wider area of Central Europe. We recommend that specific conservation efforts should be undertaken to promote natural regeneration of the core larch populations, even supplemented by the planting of seedlings derived from the oldest larch trees. Other management actions should focus on limiting external gene flow to this unique population of Polish larch.
\end{abstract}

Keywords: European larch, genetic diversity, microsatellites, spatial genetic structure

Addresses: M. Litkowiec, A. Lewandowski, Institute of Dendrology, Polish Academy of Sciences, Parkowa 5, 62-035 Kórnik, Poland, e-mail: mlit@man.poznan.pl, alew@man.poznan.pl J. Burczyk, Department of Genetics, Institute of Experimental Biology, Faculty of Natural Sciences, Kazimierz Wielki University, Chodkiewicza 30, 85-064 Bydgoszcz, Poland, e-mail: burczyk@ukw.edu.pl (D) https://orcid.org/0000-0002-6899-2523

*Corresponding author 


\section{Introduction}

The maintenance of high levels of intraspecific genetic diversity in forest tree populations is essential for the future of forest ecosystems sustainability, especially in the face of unpredictable environmental changes, including climate change and human impacts such as prolonged forest exploitation and landscape fragmentation (Hampe \& Petit, 2005; Alberto et al., 2013). Loss of genetic diversity and increase of inbreeding may result in maladaptation to variable environmental conditions and a decrease in fitness, and finally, it may lead to population extinction (Jump \& Peñuelas, 2006). Therefore understanding of population genetic structure and its determinants is essential for designing effective programs for conservation and sustainable exploitation of forest genetic resources. One of the concerns in forest genetic conservation and restoration programs is to counteract the adverse effects of forest management. For tree species of conservation importance this goal is achieved by maintaining or even enriching gene pool at the species and population levels, supporting their adaptive potential in a long-term perspective. Moreover, the fundamental practical objective of conservation genetics is to determine which populations are of fundamental importance from the perspective of genetic diversity of the species and whether they should be subjected to in-situ or ex-situ conservation efforts (Litkowiec et al., 2018).

European larch (Larix decidua Mill.) is an endemic, wind-pollinated deciduous coniferous tree species. Its natural distribution area is highly fragmented and limited to the mountains and subalpine regions: Alps, Sudetes, Carpathians (Jalas \& Suominen, 1973; Matras \& Pâques, 2008). Moreover, some small outstanding native populations have also been recorded in Central Poland and the Bihar Massif in Romanian Carpathians (Pâques et al., 2013). European larch is an ecologically and economically important tree species being cultivated throughout Europe, not only in the mountainous regions due to its fast-growing nature, high adaptability and its durable and valuable timber. From the 16th century and culminating in the 19th-century, larch was extensively planted within and beyond its natural range, leading to uncertainties about the autochthony of several populations, in particular in the Central European region (Wagner et al., 2015; Jansen \& Geburek, 2016).

Previous research on the genetic structure of $L$. decidua in Europe using different genetic marker systems (isoenzymes, microsatellites), demonstrated a high level of overall genetic variation and low differentiation between populations at the natural range distribution (Lewandowski \& Mejnartowicz, 1991; Maier, 1992; Lewandowski, 1995; Lewandowski \& Burczyk, 2000; Pluess, 2011; Mosca et al., 2012;
Wagner et al., 2015; Nardin et al., 2015; Dostálek et al., 2018). Its genetic structure has been influenced not only by strong fragmentation and geographic isolation of populations but also by population expansion related to climate change (Pluess, 2011). Extensive human impact, including human-induced translocations of non-native material and breeding, changed the composition of the gene pool of European larch (Pâques et al., 2013; Mosca et al., 2014; Wagner et al., 2015; Jansen \& Geburek, 2016).

European larch exists in a variety of climatic and ecological conditions, and it was divided into several geographic varieties, sometimes promoted to the subspecies status. For example, it is assumed that in Poland there are two subspecies of larch, and one of them with two varieties: Polish larch (Larix decidua subsp. polonica (Racib.) Domin), Sudeten larch (Larix decidua subsp. decidua var. sudetica (Domin) Svoboda) and Tatra larch (Larix decidua subsp. decidua var. adenocarpa Bobr.) (Białobok, 1986). The Polish larch is one of the most valuable fast-growing forest trees in Poland, relatively resistant to larch cancer (Pâques et al., 1999). The Świętokrzyskie Mountains is the center where the Polish larch grows between 150 and $600 \mathrm{~m}$ a.s.l., at the continental-type climate (Raciborski, 1890). However, its morphological distinctness was noticed relatively late, at the turn of the 19th and 20th centuries. Raciborski (1890) pointed out that cones of larch from Chełmowa Mountain differ from cones of larches originating from the Alps, and somewhat resemble cones of the Siberian larch. Also, the most visible feature of trees from this area, which is considered as a technical defect, is the curvature (saber) of the trunk in its lower part. Family and provenance tests indicated that such curvature is strongly inherited in populations form Chełmowa Mountain (Szafer, 1923; Bornebusch, 1948; Kocięcki, 1962; Weisgerber \& Šindelăř, 1992), with heritability of this trait estimated at 0.83 (Rożkowski et al., 2011). However, local foresters preferred larch over other conifers because of its appreciated timber and started introducing this species to cultivation at the beginning of the 19th century (Bałut, 1962; Barański, 1970). On the Chełmowa Mountain, a Natural Reserve was established in 1920 to protect the unique and natural populations of Polish larch. Currently, this reserve (13.2 ha in size) is a part of Świętokrzyski National Park. Old trees of Polish larch gradually fall out, and at the same time, there is a lack of natural regeneration. An earlier study carried out based on isoenzyme genetic markers demonstrated a lower level of genetic diversity of the Polish larch populations from Chełmowa Mountain compared to other European larch populations (Lewandowski, 1995). The hybridization between local Polish larch with other larch trees of unknown origin growing in surrounding planted stands is another unexplored 
Genetic status of Polish larch (Larix decidua subsp. polonica (Racib. Domin)) from Chełmowa Mountain 103

Table 1. Study sites and characteristics of the studied subpopulations of Polish larch

\begin{tabular}{lccccccc}
\hline $\begin{array}{c}\text { Subpopulation } \\
\text { ID }\end{array}$ & $\begin{array}{c}\text { Geographic } \\
\text { coordinates }\end{array}$ & $\begin{array}{c}\text { Sample } \\
\text { size }\end{array}$ & $\begin{array}{c}\text { Forest } \\
\text { divison }\end{array}$ & $\begin{array}{c}\text { Stand area } \\
\left(\mathrm{m}^{2}\right)\end{array}$ & $\begin{array}{c}\text { Population density } \\
\left.\text { (individuals } / \mathrm{m}^{2}\right)\end{array}$ & $\begin{array}{c}\text { Average height } \\
(\mathrm{m})\end{array}$ & $\begin{array}{c}\text { Average } \\
\text { diameter }(\mathrm{cm})\end{array}$ \\
\hline M1 (old) & $\begin{array}{l}50^{\circ} 53^{\prime} 02^{\prime \prime} \mathrm{N} \\
21^{\circ} 06^{\prime} 41^{\prime \prime} \mathrm{E}\end{array}$ & 126 & A-1h,i & 103930 & 0.0012 & 29.50 & 69.48 \\
M2 (old) & $\begin{array}{l}50^{\circ} 53^{\prime} 06^{\prime \prime} \mathrm{N} \\
21^{\circ} 06^{\prime} 02^{\prime \prime} \mathrm{E}\end{array}$ & 126 & $\mathrm{~A}-3 \mathrm{c}$ & 77783 & 0.0016 & 33.43 & 75.12 \\
M3 (young) & $\begin{array}{l}50^{\circ} 52^{\prime} 43^{\prime \prime} \mathrm{N} \\
21^{\circ} 06^{\prime} 07^{\prime \prime} \mathrm{E}\end{array}$ & 50 & $\mathrm{~A}-5 \mathrm{~d}$ & 4072 & 0.0123 & 25.78 & 41.42 \\
\hline
\end{tabular}

problem. There are plans to stimulate natural regeneration of Polish larch on the Chełmowa Mountain, but the genetic status of these populations is still unsure. In order to design effective actions for managing gene resources of Polish larch on the Chelmowa Mountain, more information is needed about the status of genetic diversity and its distribution, compared to surrounding populations.

The main aim of this study was to obtain comprehensive knowledge about the genetic diversity of Polish larch (Larix decidua subsp. polonica (Racib.) Domin) from Nature Reserve on the Chełmowa Mountain in Poland using a set of highly informative nuclear microsatellite markers. Specifically, we were interested in the following three aspects: (i) what are the levels of genetic diversity and differentiation within and among subpopulations on the Chelmowa Mountain and surrounding areas; (ii) are the studied subpopulations naturally established, which might be inferred by investigating spatial genetic structure of subpopulations; (iii) how homogeneous are studied subpopulations and what is their relationship to the ancestral groups of European larch defined in earlier studies of this species across Europe. We anticipate that our results will provide indications on the future strategies for gene conservation of Polish larch on the Chelmowa Mountain, and will serve as a case study for solving gene conservation problems in similar scenarios.

\section{Material and Methods}

\section{Plant material}

Material for genetic analysis came from three subpopulations of Polish larch (Larix decidua subsp. polonica (Racib. Domin) growing in Nature Reserve on the Chełmowa Mountain, in the Forest District Lagów, Poland (Table 1). The subpopulation M1 was selected in the forest compartments A-1h and A-1i. Here, larch trees were over 190 years old and they shared $30-40 \%$ of the stand, coexisting with oak (Quercus robur L.) and beech (Fagus sylvatica L). The subpopulation M2 was located in the forest compartment A-3c. The contribution of larch in this stand was similar to M1 (40\%); however, larch trees were slightly younger (about 170 years old) and they coexisted with beech trees only. On the other hand, the subpopulation M3 located in the forest compartment A-5d was the youngest (trees were 60 years old) sharing about $70 \%$ of the stand. Additionally, the 42 elite plus-trees of Polish larch originating from a wider area of Świętokrzyskie Mountains were sampled as a reference subpopulation for the genetic analyses, and they were marked as subpopulation M4. All trees were measured for dbh (diameter at breast height) and height and were georeferenced. In total, 344 individuals of Polish larch were sampled for analyses.

Table 2. Basic characteristics of the eleven nuclear microsatellite loci in Larix decidua subsp. polonica used in this study: $A$ - number of alleles; $A_{\mathrm{e}}$ - effective number of alleles; $A R$ - allelic richness (after rarefaction correction); $H_{\mathrm{o}}-$ observed heterozygosity; $H_{\mathrm{e}}$ - expected heterozygosity; $F_{\mathrm{is}}$ - inbreeding coefficient (the coefficients denoted with asterisk $\left(^{*}\right.$ ) are significantly different from zero at the level of $\mathrm{p}<0.001)$; NO - null alleles frequency; $F_{\text {st }}$ - coefficient of genetic differentiation for loci; $F_{\text {stENA }}$ - coefficient of genetic differentiation with correction for null alleles.

\begin{tabular}{lrrrrrrrrc}
\hline \multicolumn{1}{c}{ Locus } & $\mathrm{A}$ & $\mathrm{A}_{\mathrm{e}}$ & \multicolumn{1}{c}{$\mathrm{AR}$} & $\mathrm{H}_{\mathrm{o}}$ & $\mathrm{H}_{\mathrm{e}}$ & $\mathrm{F}_{\text {is }}$ & $\mathrm{N} 0$ & $\mathrm{~F}_{\text {st }}$ & $\mathrm{F}_{\text {stENA }}$ \\
\hline LD31 & 18 & 5.44 & 11.46 & 0.848 & 0.810 & -0.047 & 0.02 & 0.011 & 0.011 \\
LD42 & 8 & 4.30 & 6.29 & 0.807 & 0.766 & -0.053 & 0.02 & 0.013 & 0.013 \\
LD45 & 8 & 3.36 & 6.21 & 0.688 & 0.678 & -0.015 & 0.03 & 0.044 & 0.043 \\
LD50 & 16 & 6.81 & 10.62 & 0.799 & 0.852 & 0.062 & 0.05 & 0.013 & 0.012 \\
LD56 & 12 & 6.40 & 9.23 & 0.815 & 0.842 & 0.032 & 0.03 & 0.004 & 0.004 \\
LD101 & 5 & 1.38 & 3.90 & 0.245 & 0.258 & 0.051 & 0.06 & 0.037 & 0.047 \\
bcLK189 & 13 & 6.07 & 9.72 & 0.813 & 0.835 & 0.026 & 0.03 & 0.015 & 0.016 \\
bcLK211 & 29 & 6.24 & 14.86 & 0.856 & 0.832 & -0.029 & 0.02 & 0.022 & 0.022 \\
bcLK228 & 17 & 10.15 & 14.45 & 0.868 & 0.900 & $0.036^{*}$ & 0.03 & 0.019 & 0.019 \\
bcLK229 & 11 & 2.79 & 7.16 & 0.412 & 0.570 & $0.278^{*}$ & 0.12 & 0.091 & 0.075 \\
bcLK263 & 26 & 7.60 & 14.73 & 0.765 & 0.867 & $0.118^{*}$ & 0.06 & 0.009 & 0.010 \\
Mean & 14.8 & 5.50 & 9.88 & 0.720 & 0.746 & $0.042^{*}$ & 0.04 & 0.025 & 0.025 \\
\hline
\end{tabular}




\section{Microsatellite analyses}

Total genomic DNA was extracted from 50mg of dried needles using GeneMATRIX Plant \& Fungi DNA Purification kit (EURx Ltd, Poland) following the manufacturer's protocol. All individuals were genotyped at eleven nuclear microsatellite markers (SSRs): bcLK189, bcLK211, bcLK229, bcLK228, bcLK263 (Isoda \& Watanabe, 2006) and LD31, LD42, LD45, LD50, LD56, LD101 (Wagner et al., 2012), combined in two multiplex PCR reactions. Multiplex 1 consisted of six primers: bcLK189, bcLK211, $L D 31, L D 45, L D 50$ and $L D 56$, at concentrations of $0.125 \mu \mathrm{M}$ and $0.2 \mu \mathrm{M}, 0.1 \mu \mathrm{M}, 0.1 \mu \mathrm{M}, 0.1 \mu \mathrm{M}$ and $0.1 \mu \mathrm{M}$, respectively. Multiplex 2 consisted of five primers: bcLK228, bcLK229, bcLK263, LD42 and LD101, at concentrations $0.125 \mu \mathrm{M}, 0.125 \mu \mathrm{M}, 0.15$ $\mu \mathrm{M}, 0.125 \mu \mathrm{M}$ and $0.15 \mu \mathrm{M}$, respectively. The PCR multiplex reactions for each sample were performed in a total volume of $10 \mu \mathrm{l}$ using a Qiagen Multiplex Master Mix kit (Qiagen, Germany) according to manufacturer's protocol and 10ng of template DNA. The PCRs conditions for both multiplex reactions were the same with an initial denaturation step at $95{ }^{\circ} \mathrm{C}$ for $15 \mathrm{~min}$, followed by 32 cycles at $94{ }^{\circ} \mathrm{C}$ for $30 \mathrm{~s}, 1 \mathrm{~min}$ at $56^{\circ} \mathrm{C}, 1 \mathrm{~min}$ at $72{ }^{\circ} \mathrm{C}$, and a final extension at $60^{\circ} \mathrm{C}$ for $30 \mathrm{~min}$. The fluorescently labeled PCR products, along with a size standard (GeneScan 500 LIZ), were separated on a capillary sequencer ABI 3130xl (Applied Biosystems, USA). The results were analyzed using GeneScan 3.7 and Genotyper 3.7 provided by the manufacturer. All size variants were checked, binned to alleles and approved manually.

\section{Data analysis}

The linkage disequilibrium between the pairs of loci was assessed at the single subpopulation level and across all subpopulations, and its significance was tested with a Bonferroni correction using FsTAT v. 2.9.3 software (Goudet, 2001). Genetic diversity within and among subpopulations was assessed based on the following parameters: the number of alleles $(A)$; allelic richness $(A R)$ corrected for a minimum sample size of 42 individuals (subpopulation M4), observed heterozygosity $\left(H_{\circ}\right)$, and expected heterozygosity $\left(H_{\mathrm{e}}\right)$, all of which were computed using Fstat v 2.9.3. The effective number of alleles $\left(A_{\mathrm{e}}\right)$ was calculated using GenAlEx 6 software package (Peakall \& Smouse, 2006). The extent of deviation from Hardy-Weinberg proportions was tested using the exact test based on Markov Chain Monte Carlo (MCMC) algorithm, and the Wright's fixation index $\left(F_{\text {is }},\right)$ averaged over all loci and subpopulations was calculated, using Genepop v. 4.0 (Raymond \& Rousset, 1995; Rousset, 2008).
The microsatellite loci used in this study were tested for the presence of null alleles (NO) using the Individual Inbreeding Model (IIM) with a Gibbs sampler of $10^{5}$ iterations implemented in INEst v. 2.0 software (Chybicki \& Burczyk, 2009). Because all loci experienced null alleles, the inbreeding coefficients $\left(F_{\text {isNull }}\right)$ were calculated for each subpopulation using a Bayesian procedure (IIM) implemented in INEST 2.0 software. The calculations were performed using the 'nfb' model (null alleles, inbreeding coefficients, and genotyping failures) and 'nb' model (null alleles and genotyping failures) to detect inbreeding effects in our dataset, using 100,000 MCMC iterations, with the $100^{\text {th }}$ updated and a burn-in of 10,000 . The Deviance Information Criterion (DIC) was used to determine the best model by comparing the full model with the random mating model (under an assumption of $F_{\text {is }}=0$ ).

Genetic differentiation among subpopulations was assessed using $F_{\text {st }}$ statistics, which was tested for significance based on 10000 permutations using SPAGeDi 1.5 (Hardy \& Vekemans, 2002). Due to the presence of null alleles, the $F_{\mathrm{st}}$ estimates were calculated using FreeNA software (Chapuis \& Estoup, 2007). The bootstrapped $95 \%$ confidence intervals (CIs) of the global $F_{\text {stENA }}$ were calculated using 5000 replicates over the loci. Principal coordinates analysis (PCoA) to graphically represent genetic relationships among subpopulations was further performed using GenAlEx 6 software package based on the covariance matrix of genetic distance $\left(F_{\mathrm{stENA}}\right.$ generated by FreeNA software) with data standardization. The contemporary effective population size $\left(N_{\mathrm{e}}\right)$ was calculated for each subpopulations using the linkage disequilibrium (LD) method implemented in NeEstimator 2.01 software (Do et al., 2014), with random mating model and a threshold of excluding rare alleles at $P_{\text {crit }}=0.02$, which seems typical for microsatellites.

Spatial genetic structure (SGS) within subpopulations M1, M2, M3 was evaluated using a spatial autocorrelation analysis. Kinship coefficients $F_{\mathrm{ij}}$ (Loiselle et al., 1995) were estimated in nine (subpopulations M1 and M2) or seven distance classes (subpopulation M3), selected in order to provide a sufficient number of comparable pairs of individuals within each class. In the subpopulations M1 and M2, the intervals were set as: $0-10 \mathrm{~m}, 10-20 \mathrm{~m}, 20-40 \mathrm{~m}$, $40-60 \mathrm{~m}, 60-80 \mathrm{~m}, 80-100 \mathrm{~m}, 100-150 \mathrm{~m}, 150$ $-200 \mathrm{~m},>200 \mathrm{~m}$; but for the subpopulation M3, the intervals were defined as follows: $0-5 \mathrm{~m}, 5-10 \mathrm{~m}$, $10-20 \mathrm{~m}, 20-40 \mathrm{~m}, 40-60 \mathrm{~m}, 60-80 \mathrm{~m},>80 \mathrm{~m}$. The significance of autocorrelation was tested using a permutational test and $95 \%$ confidence intervals around null hypothesis estimates were obtained by permuting individual locations 10000 times. Confidence intervals for average kinship coefficients were 
obtained using standard errors computed through jackknifing over loci (Sokal \& Rohlf, 1995). All kinship analyses were performed with SPAGEDI v.1.5 (Hardy \& Vekemans, 2002).

The Sp statistics (Vekemans \& Hardy, 2004) was calculated to compare the intensity of SGS among cohorts, according to $S p=b_{\log } /(1-F(1))$, where $b_{\log }$ is the regression slope of $F_{\mathrm{ij}}$ on the natural logarithm of the distance $r$, between individuals $i$ and $j, \ln \left(r_{\mathrm{ij}}\right)$, and $\mathrm{F}(1)$ is the mean $F_{\mathrm{ij}}$ among individuals of the first distance class $(0-20 \mathrm{~m}$ or $0-5 \mathrm{~m})$ which is expected to include all pairs of near neighbors.

The subpopulations investigated in this study were related to ancestral genetic groups defined by Wagner et al. (2015) in order to assess the level homogeneity or admixture which could result from possible long-distance seed transfer (Wagner et al., 2015; Jansen \& Geburek, 2016). For this purpose, we combined the original dataset presented by Wagner et al. (2015) with the dataset obtained in this study. However, only nine loci (except bcLK229, bcLK228) common to both datasets were used for the analyses. Because allele sizing performed by different laboratories can lead to different results, allele calls (fragment sizes) of our dataset were adjusted to the allele calls used in the study of Wagner et al. (2015) by comparing the allele frequency spectra of our data with those observed in the subset of Central European populations presented in Wagner et al. (2015). It appeared that in three loci ( $b c L K 263, L D 42, L D 50)$ no adjustment was needed, in four loci ( $b c L K 189$, bcLK211, LD101, LD45) allele calls were increased by $1 \mathrm{bp}$, in one locus (LD31) they were increased by $2 \mathrm{bp}$, and in one locus (LD56) allele calls were decreased by $2 \mathrm{bp}$.

The combined dataset was analyzed using StrucTURE ver. 2.3.4. (Pritchard et al., 2000) assuming the presence of two $(K=2)$ or seven $(k=7)$ genetic groups (clusters), defined by Wagner et al. (2015), where the main group $K 1$ is composed of clusters $k 1-k 4$ representing Alpine populations, and the group $K 2$ is composed of clusters $k 5-k 7$ representing Central European populations (see: Wagner et al., 2015). We assumed the admixture model with correlated allele frequencies and no prior information about populations' locations. The Monte Carlo Markov Chain (MCMC) sampling scheme was run for 500000 iterations with a 200000 burn-in period. The StRUCtURE analysis provided the membership coefficients of individuals ( $Q$-matrix) for each of the defined genetic clusters (assignment probabilities). An individual was arbitrarily assigned to a specific genetic group (cluster) based on the largest value of $q$, when the largest $q$ was greater than the second largest $q$ by more than 0.1 . Otherwise, the individual was assigned to two clusters with the largest $q$ values.

\section{Results}

\section{Genetic diversity and differentiation}

All microsatellite loci used in this study appeared to be polymorphic and they all provided high-quality and repeatable amplification. No evidence for linkage disequilibrium was detected between pairs of loci across all subpopulations after Bonferroni adjustment. The measures of genetic diversity for eleven loci are summarized in table 2. A total number of 163 alleles was found across 344 analyzed individuals. The number of alleles per locus $(A)$ ranged from 5 (LD101) to 29 (bcLK211), with an average of 14.8 . In general, the effective number of alleles was low and averaged at 5.5. The mean observed and expected heterozygosities were similar $\left(H_{\mathrm{o}}=0.720\right.$ and $H_{\mathrm{e}}$ $=0.746$, respectively). The microsatellite loci used for the genetic analysis experienced the presence of null alleles at low frequencies within the range from 0.02 (LD31, LD42, bcLK211) to 0.12 (bcLK229), with an average of 0.04 across all loci. Noteworthy, there was significant correlation between $F_{\text {is }}$ and $N O(r=$ 0.964; $p<0.0001$ ).

The frequency of null allele was well below the level 0.2 at which null alleles could result in a significant underestimate the F-statistics (Chapuis \& Estoup, 2007). Therefore the $F_{\text {stENA }}$ estimates corrected for the presence of null alleles were quite similar to uncorrected estimates. The studied subpopulations were the least differentiated at the LD56 locus $\left(F_{\text {stENA }}\right.$ $=0.004)$, and the most differentiated at the $b c L K 229$ locus $\left(F_{\text {stENA }}=0.075\right)$.

Measures of genetic diversity averaged across loci for each subpopulation are summarized in table 3 . The two older subpopulations M1 and M2 were particularly similar and they exhibited slightly lower levels of genetic diversity compared to other subpopulations. The average number of alleles $(A)$ within subpopulations ranged from 9.5 (M1) to 12.0 (M4), with the mean of 10.6. The average effective number of alleles was equal to 5.5. The lowest effective number of alleles was found in the subpopulation M1 $\left(A_{\mathrm{e}}\right.$ $=4.7)$ and the highest in the population $\mathrm{M} 4\left(A_{\mathrm{e}}=\right.$ 6.2). The allelic richness (AR) ranged from 8.2 (M1) to 11.9 (M4), with an average of 9.8. The observed heterozygosity $\left(H_{\mathrm{o}}\right)$ (average $=0.720$, range: $0.672-$ $0.0773)$ was similar to expected heterozygosity $\left(H_{\mathrm{e}}\right)$ (average $=0.752$, range: 0.694-0.805).

In all subpopulation the estimates of $F_{\text {is }}$ suggested significant levels of inbreeding (Table 3). However, when $F_{\text {is }}$ was calculated with accounting for the presence of null alleles, such estimates $\left(F_{\text {isNull }}\right)$ appeared to be low and not significantly different from zero, indicating no signatures of inbreeding. This means that $F_{\text {is }}$ estimates were somehow biased by the presence of null alleles. 
Table 3. Summary of multilocus analyses of genetic diversity of subpopulations of Larix decidua subsp. polonica. $N$ - number of sampled individuals; $A$ - averaged number of alleles; $A_{\mathrm{e}}$ - effective number of alleles; $A R$ - averaged allelic richness (after rarefaction); $H_{\mathrm{o}}$ - observed heterozygosity; $H_{\mathrm{e}}$ - expected heterozygosity; $F_{\text {is }}$ - inbreeding coefficient; $N O$ - frequency of null alleles; $F_{\text {isNull }}$ - inbreeding coefficient with null alleles correction

\begin{tabular}{|c|c|c|c|c|c|c|c|c|c|}
\hline Subpopulation & $\mathrm{N}$ & A & $\mathrm{A}_{\mathrm{e}}$ & AR & $\mathrm{H}_{\mathrm{o}}$ & $\mathrm{H}_{\mathrm{e}}$ & $\mathrm{F}_{\mathrm{is}}$ & NO & $\mathrm{F}_{\text {isNull }}$ \\
\hline M1 (old) & 126 & 9.5 & 4.7 & 8.2 & 0.672 & 0.694 & $0.031^{* *}$ & 0.03 & $0.005^{\mathrm{ns}}$ \\
\hline M2 (old) & 126 & 9.6 & 5.0 & 8.3 & 0.709 & 0.725 & $0.021^{* * *}$ & 0.03 & $0.005^{\mathrm{ns}}$ \\
\hline M3 (young) & 50 & 11.2 & 6.1 & 10.7 & 0.723 & 0.785 & $0.079^{* * *}$ & 0.06 & $0.020^{\text {ns }}$ \\
\hline M4 (set of elite plus trees) & 42 & 12.0 & 6.2 & 11.9 & 0.773 & 0.805 & $0.040^{*}$ & 0.04 & $0.016^{\mathrm{ns}}$ \\
\hline Mean & 344 & 10.6 & 5.5 & 9.8 & 0.720 & 0.752 & $0.043^{* * *}$ & 0.04 & $0.012^{\mathrm{ns}}$ \\
\hline
\end{tabular}

Level of significance that $F_{\text {is }}$ or $F_{\text {isNull }}>0:{ }^{*}-p<0.05 ;{ }^{* *}-p<0.01 ;{ }^{* * *}-p<0.001$; ns - not significant.

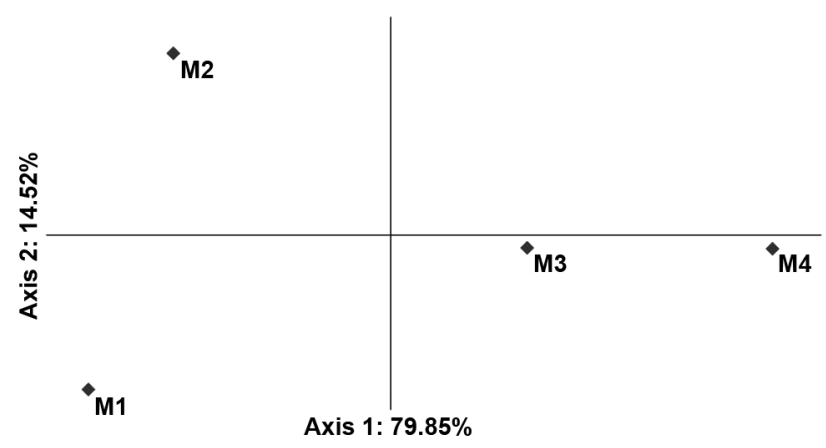

Fig. 1. Results of Principal Coordinates Analysis (PCoA) based on 11 nuclear microsatellite markers in four subpopulations of Larix decidua subsp. polonica

The overall subpopulation genetic differentiation was low, however statistically significant $\left(F_{\mathrm{st}}=\right.$ 0.022; CI95\% $=0.013-0.036)$. All pairwise $F_{\text {st }}$ values among subpopulations were also significant $(p<$ $0.001)$. The ENA correction affected the estimates to a little degree $\left(F_{\text {stENA }}=0.021 ; \mathrm{CI} 95 \%=0.013-0.032\right)$; which means that the existing null alleles had a minor effect on the estimates of genetic differentiation.

The genetic relationship among subpopulations was identified through the Principal Coordinate Analysis (PCoA). The first and second axes of the PCoA explained $79.85 \%$ and $14.52 \%$ of the total variation, respectively (Fig. 1). The two subpopulations M1 and M2 were well separated from M3 and M4 along the Axis 1.

Table 4 . The contemporary effective population size $\left(N_{\mathrm{e}}\right)$ for the studied subpopulations of Larix decidua subsp. polonica based on the linkage disequilibrium method $\left(N_{\text {eLD }}\right)$ with a $95 \%$ confidence interval

\begin{tabular}{lcrc}
\hline \multicolumn{1}{c}{ Subpopulaion } & Sample size & $\mathrm{N}_{\mathrm{eLD}}$ & \multicolumn{1}{c}{ CI95\% } \\
\hline M1 (old) & 126 & 94.6 & $73.6-126.4$ \\
M2 (old) & 126 & 88.6 & $73.4-109.0$ \\
M3 (young) & 50 & 95.6 & $72.4-136.1$ \\
M4 (set of elite plus trees) & 42 & 83.9 & $61.2-127.5$ \\
Harmonic mean & 344 & 90.7 & \\
\hline M1 + M2 & 252 & 155.4 & $127.7-192.7$ \\
M1 + M2 + M3 & 302 & 209.4 & $172.1-260.3$ \\
M1 + M2 + M3 + M4 & 344 & 226.8 & $194.8-267.4$ \\
\hline
\end{tabular}

\section{Effective population size}

The estimates of effective population size obtained based on the linkage disequilibrium method $\left(N_{\mathrm{eLD}}\right)$ were large and homogeneous across subpopulations, and they ranged from 83.9 (M4) to 95.6 (M3), with an overall harmonic mean equal to 90.7 (Table 4). Differences in $N_{\text {eLD }}$ between subpopulations were not significant. The $N_{\text {eLD }}$ was also evaluated by combining different sets of subpopulations. In all cases merging of subpopulations resulted in a continuous increase of the estimates of effective populations size indicating that the subpopulations represent rather complementary than multiplicated gene pools.

\section{Spatial genetic structure}

We found the evidence of spatial genetic structure in both older subpopulations M1 and M2; however, the pattern of isolation by distance seemed to be slightly more emphasized in the subpopulation M2 (Table 5). The pairwise kinship coefficients in these cases were significant for pairs of individuals

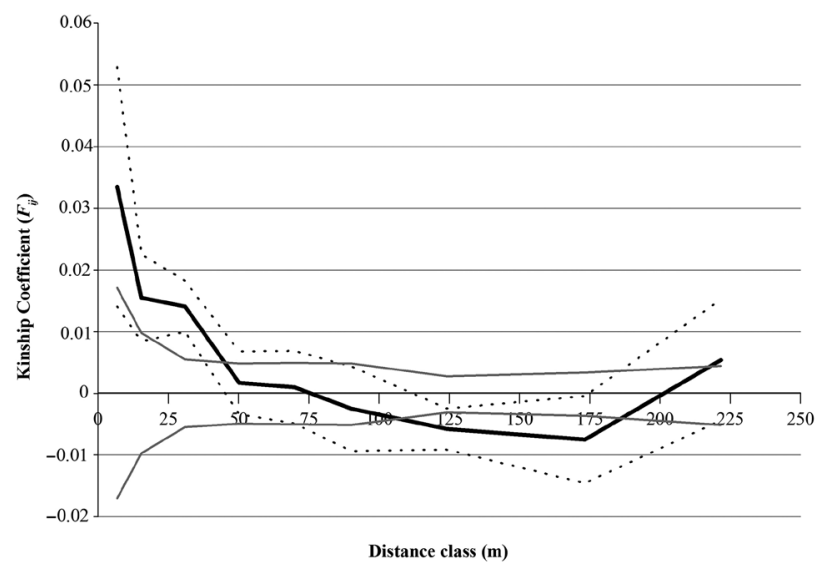

Fig. 2. Autocorrelogram of kinship coefficients $\left(F_{i j}\right)$ against the logarithm of distance obtained for the subpopulation M1 (old individuals) of Larix decidua subsp. polonica (dotted lines represent 95\% confidence interval around the estimates of $\mathrm{F}_{\mathrm{ij}}$ determined based on jackknife procedure over loci; grey lines indicate $95 \%$ confidence interval around the null distribution of kinship coefficients derived from 10,000 permutations) 


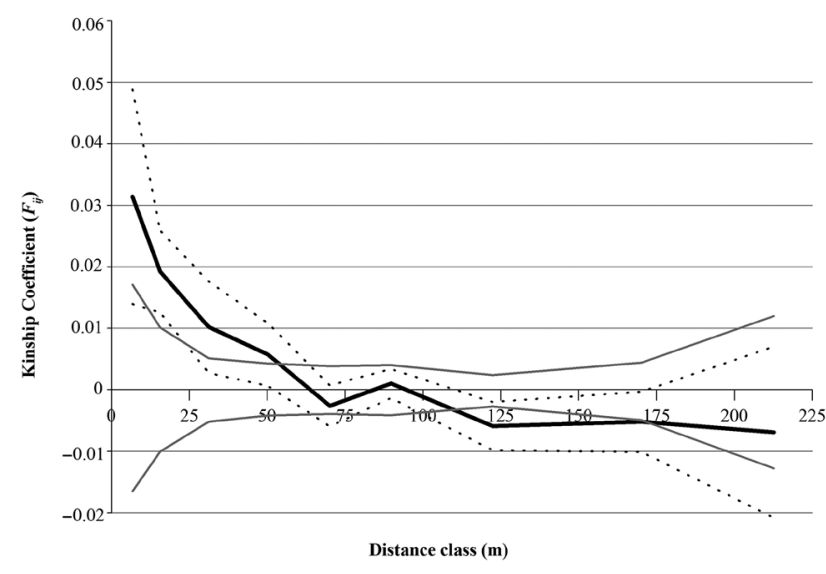

Fig. 3. Autocorrelogram of kinship coefficients $\left(F_{i j}\right)$ against the logarithm of distance obtained for the subpopulation M2 (old individuals) of Larix decidua subsp. polonica (dotted lines represent 95\% confidence interval around the estimates of $\mathrm{F}_{\mathrm{ij}}$ determined based on jackknife procedure over loci; grey lines indicate $95 \%$ confidence interval around the null distribution of kinship coefficients derived from 10000 permutations)

separated up to about 50 meters (Fig. 2 and 3), but they were not significant at any distance for the subpopulation M3. The mean level of kinship coefficients in the first distance class (near neighbors) was similar in M1 and M2 subpopulations, and it was twice as high as in subpopulation M3 (Fig. 4). Similarly, the slope of the regression of kinship coefficients on the logarithm of distance $\left(b_{\text {log }}\right)$ between individuals was significant for subpopulations M1 and M2 $(-0.0083$ and -0.0105 , respectively), but it was not

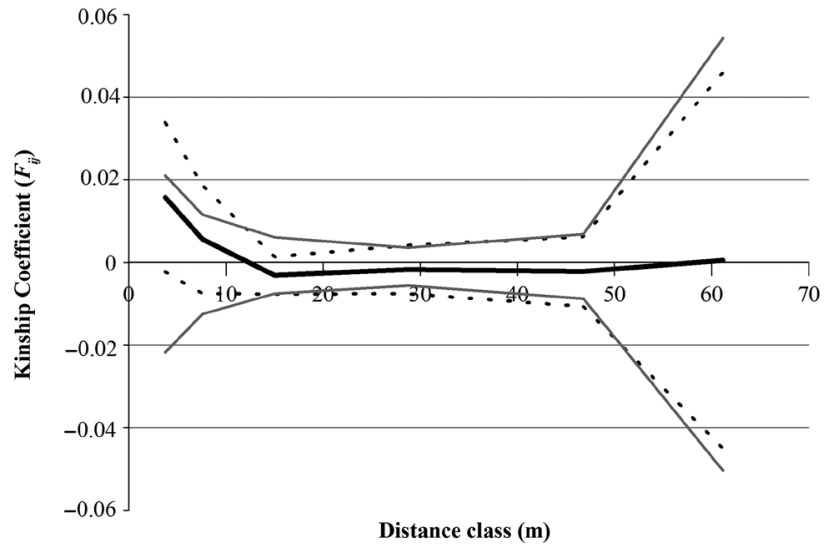

Fig. 4. Autocorrelogram of kinship coefficients $\left(F_{i j}\right)$ against the logarithm of distance obtained for the subpopulation M3 (young individuals) of Larix decidua subsp. polonica (dotted lines represent 95\% confidence interval around the estimates of $\mathrm{F}_{\mathrm{ij}}$ determined based on jackknife procedure over loci; grey lines indicate $95 \%$ confidence interval around the null distribution of kinship coefficients derived from 10000 permutations)

significant for subpopulation M3. Consequently, the Sp statistics indicated a weak but significant pattern of isolation by distance in both older subpopulations (0.0086 and 0.0108), but not in the subpopulation consisted of younger trees (0.0008; Table 5).

\section{Relationship to ancestral genetic groups}

We related the studied subpopulations to genetic groups of L. decidua defined by Wagner et al. (2015).

Table 5. Summary of spatial genetic structure (SGS) parameters estimated for three subpopulations of Larix decidua subsp. polonica. Sp - the intensity of SGS; $b_{\log }$ - a slope of regression of kinship coefficients agains the logarithm of distance between individuals, $F 1$-the mean kinship coefficient within the first distance class (see text); $N b$ - neighborhood size, $\sigma$ - mean axial gene dispersal distance

\begin{tabular}{lcccccrr}
\hline Subpopulation & Sample size & $\mathrm{Sp}$ & $\mathrm{b}_{\log }(\mathrm{SE})$ & Density & $\mathrm{F}_{1}$ & \multicolumn{1}{c}{$\mathrm{Nb}$} & $\sigma$ \\
\hline M1 (old) & 126 & 0.0086 & $-0.0083(0.0014)$ & 0.0012 & 0.0335 & 116.64 & 87.81 \\
M2 (old) & 126 & 0.0108 & $-0.0105(0.0024)$ & 0.0016 & 0.0314 & 92.23 & 67.86 \\
M3 (young) & 50 & 0.0008 & $-0.0044(0.0026)$ & 0.0123 & 0.0158 & 1234.08 & 89.93 \\
\hline
\end{tabular}

Table 6. Mean probability of individual assignment to two major genetic groups $(K 1-K 2)$ and to seven genetic clusters ( $k 1-k 7)$ defined by Wagner et al. (2015), based on STRUCTURE analyses ( $q$-value). Group K1 - Alpine populations, group $K 2$ - Central European populations, clusters $k 1-k 4$ - Alpine populations (group K1); cluster $k 5$ - Sudetes, cluster $k 6$ Polish lowlands, cluster $k 7$ - Carpathians

\begin{tabular}{ccccc}
\hline Major genetic groups & Subpopulation M1 & Subpopulation M2 & Subpopulation M3 & Subpopulation M4 \\
\hline K1 & 0.066 & 0.067 & 0.168 & 0.152 \\
K2 & 0.934 & 0.933 & 0.832 & 0.848 \\
\hline Genetic clusters & & & 0.034 & 0.040 \\
$k 1$ & 0.014 & 0.013 & 0.052 & 0.025 \\
$k 3$ & 0.016 & 0.016 & 0.050 & 0.030 \\
$k 4$ & 0.029 & 0.027 & 0.073 & 0.056 \\
$k 5$ & 0.019 & 0.025 & 0.196 & 0.369 \\
$k 6$ & 0.054 & 0.040 & 0.478 & 0.218 \\
$k 7$ & 0.844 & 0.841 & 0.117 & 0.261 \\
\hline
\end{tabular}


Initially, we assumed just two main genetic groups $(K=2)$ (group K1 composed of clusters 1-4 - Alpine populations; group $K 2$ composed of clusters 5-7 Central European populations; Wagner et al., 2015). In this case, all individuals of subpopulations M1 and M2 were assigned to group K2; however, in each of the subpopulations M3 and M4, just two individuals were assigned to group $K 1$, with the remaining ones assigned to $K 2$. The mean probabilities of assignment of individuals to group $K 1$ and $K 2$ for each subpopulation are presented in Table 6 .

Subsequently, we attempted to assign the studied individuals to the seven genetic clusters defined by Wagner et al. (2015). Individuals from subpopulations M1 and M2 were almost exclusively assigned to the cluster $k 6$ (Polish lowlands), with $96.82 \%$ and $95.24 \%$ of individuals assigned from each of these subpopulations, respectively. On the other hand, the subpopulations M3 and M4 were less homogeneous. In the subpopulation M3, 18\%, 54\% and $12 \%$ of individuals were assigned to clusters $k 5, k 6$, and $k 7$, respectively, but in the subpopulation M4 analogous numbers were equal to $40.48 \%, 21.43 \%$, and 28.57\%. In both M3 and M4 subpopulations, several individuals exhibited shared assignment among two genetic clusters. Mean assignment probabilities to genetic clusters of $L$. decidua defined by Wagner et al. (2015) are presented in table 6. Notably, the distribution of assignment probabilities indicated apparent homogeneity of genetic pools of the subpopulations M1 and M2, but on the other hand distinct heterogeneity of subpopulation M3, or even greater heterogeneity of the subpopulation M4.

\section{Discussion}

In this study, we investigated neutral genetic diversity and differentiation of Polish larch (Larix decidua subsp. polonica (Racib. Domin)) populations growing in the Nature Reserve on the Chełmowa Mountain (Poland) and surrounding areas, based on the highly informative eleven nuclear microsatellite markers. Consistent with previous studies on coniferous tree species (e.g., Wagner et al., 2012; Wójkiewicz et al., 2016; Litkowiec et al., 2018), we found a low level of null alleles (4\%), which did not affect the estimates of genetic diversity or differentiation across the studied subpopulations.

In general, the patterns of genetic diversity and differentiation obtained for subpopulations of Polish larch (Larix decidua subsp. polonica (Racib. Domin)) are in line with other studies on temperate tree species (e.g., Hamrick et al., 1992; Nybom, 2004; Petit \& Hampe, 2006). We found no evidence of inbreeding and not significant departure from Hardy-Weinberg equilibrium. The subpopulations exhibited high levels of genetic diversity and low genetic differentiation. Our results are in agreement with the results derived based on nSSRs, from populations of European larch from the Swiss Alps $(\mathrm{He}=0.750)$ (Pluess, 2011), the French Alps $(\mathrm{He}=0.760)$ (Nardin et al., 2015), the Romanian Carpathians ( $\mathrm{He}=$ 0.738) (Gramazio et al., 2018) and even entire natural range $(\mathrm{He}=0.686)$ (Dostálek et al., 2018).

Low or moderate level of genetic differentiation in forest trees is maintained due to the large size of populations, extensive gene flow and phenotypic plasticity (Petit \& Hampe, 2006). Here we found low, although significant, levels of genetic differentiation among subpopulations $\left(F_{\text {st }}=0.022 \mathrm{p}<0.001\right)$, which is not surprising given the rather small geographic scale of the study. It indicates that only $2.2 \%$ of the genetic variation may be attributed to the differences among subpopulations. The presence of null alleles had a minor effect on the $F_{\text {st }}$ estimate $\left(F_{\text {stENA }}=\right.$ $0.021)$. The two subpopulations M1 and M2 were the least differentiated suggesting that they represent the same gene pool. Our results are in agreement with the levels of genetic differentiation observed in $L$. decidua at local and regional scales using different marker systems (Dostálek et al., 2018). Pluess (2011) has reported $F_{\text {st }}$ value of 0.014 on a local scale based on nuclear SSR data. Distinctly higher value of $F_{\text {st }}(0.043)$ was recorded on a broader scale by Mosca et al. (2012) applying nuclear SNPs.

In our study, the two subpopulations of old trees (M1 and M2), exhibited distinctly lower levels of genetic diversity, as compared to the younger (M3) and the reference (M4) subpopulations (Table 3). The distinctness of M1 and M2 subpopulations was confirmed by PCoA analysis. Additionally, based on StruCtURE analyses, the subpopulations M1 and M2 appeared to be mostly homogeneous and almost all individuals were assigned exclusively to cluster $k 6$ (Table 6) representing Polish lowland populations (Wagner et al., 2015). These two subpopulations likely represent native gene pools, because their weak but significant spatial genetic structure suggests that they were established following natural reproductive processes (Vekemans \& Hardy, 2004; Jump \& Peñuelas, 2007; Paffetti et al., 2012).

Interestingly, Lewandowski (1995) using isoenzymes as genetic markers demonstrated low level of genetic variation of the Polish larch from Chełmowa Mountain $\left(H_{\mathrm{e}}=0.085\right)$, as compared to other larch populations. The author postulated that this population could have originated from a relatively low number of parental trees (founder effect) left in the forest due to their low timber quality (curvature of the main stem). Indeed, the decrease of effective population size due to stochastic events such as bottleneck or founder effect may reduce the genetic diversity of populations and elevate levels of inbreeding which 
might be detrimental for population persistence (Robledo-Arnuncio et al., 2004). However, in all subpopulations studied we found relatively high levels of effective population sizes, typical for tree species characterized by broad, continuous natural distribution and extensive gene flow (Frankham, 1995).

The subpopulation M4 composed of widely distributed individuals sampled from various populations in the region of Świętokrzyskie Mountains, considered here as a reference sample, not surprisingly appeared to be the most diverse (Table 3) and the least homogeneous subpopulation (Table 6). However, the subpopulation M3 composed of young trees about 60 years old located at the southern edge of Nature Reserve on Chełmowa Mountain was also genetically highly diverse, with no evidence of spatial genetic structure which suggests its artificial establishment. Notably, in contrary to old trees from M1 and M2 subpopulations, almost all trees growing in the subpopulation M3 are characterized with straight stems without curvature and saber trunk, which is typical for old trees growing on Chelmowa Mountain (Szafer, 1923; Bornebusch, 1948; Kocięcki, 1962; Weisgerber \& Šindelăř, 1992). The subpopulation M3 was mostly heterogeneous (Table 6) in respect to the relationship of individuals to ancestral gene pools of larch identified in Europe by Wagner et al. (2015). This confirms its artificial origin but also points out that it is unlikely that the seeds used for establishment of subpopulation M3 originated from the old core populations located on the Chełmowa Mountain, but rather seeds originated from many other although Central European populations.

Local foresters have planted European larch since the sixteen century and in the late 19th century this phenomenon intensified. Historical documents indicated that Tyrol and Sudetes were the primary sources of larch seeds transported and utilized across a wide range of the natural distribution of this species (Münch, 1936). Wagner et al. (2015) based on mitochondrial and nuclear markers concluded that several European larch populations represent the admixture of native and non-native populations from multiple sources nowadays. They revealed that translocation events (seed deployment) were especially frequent in Poland, Slovakia, and the Czech Republic. In Europe, the phenomena of the large-scale transfer of forest reproductive material are well documented for other tree species (Lewandowski et al., 2014; Myking et al., 2016; Jansen et al., 2017).

The population of Polish larch from Chełmowa Mountain is at risk of extinction. To preserve genetic resources of this undoubtedly unique larch ecotype it is necessary to design efficient strategy for its conservation. All efforts should be made to increase the efficiency of natural regeneration, but the artificial planting of seedlings derived from seeds harvested from old trees of Polish larch from Chełmowa Mountain should also be considered as a complementary treatment for in-situ conservation. However, it is unclear to what extent the population of Polish larch at the Chelmowa Mountain is isolated and protected from gene flow from external surrounding natural and artificial larch stand. This problem needs to be addressed in future studies.

\section{Acknowledgements}

The study was supported by Forest Fund of State Forests, Poland (grant no. EZ.0290.1.34.2017) and Świętokrzyski National Park. The authors are thankful to Katarzyna Meyza and Ewa Sztupecka for laboratory assistance, and to Pawel Szczepaniak and Lech Buchholz from Świętokrzyski National Park for sampling of material and useful comments on earlier draft of the manuscript. The authors wish to thank Stefanie Wagner and Remy Petit for sharing their microsatellite genotypic data of European larch populations.

\section{References}

Alberto FJ, Aitken SN, Alıa S, Gonzalez-Martinez SC, Hänninen $\mathrm{H}$, Kremer A, Lefèvre F, Lenormand T, Yeaman S, Whetten R \& Savolainen O (2013) Potential for evolutionary responses to climate change - evidence from tree populations. Global Change Biology 19: 1645-1661. doi:10.1111/ gcb. 12181 .

Bałut S (1962) Zmienność niektórych cech w populacjach modrzewia z Gór Świętokrzyskich, Beskidów i Sudetów jako podstawa wyróżniania gospodarczo cennych ekotypów. Acta Agraria et Silvestria series Silvestris 2: 3-43.

Barański S (1970) Występowanie i uprawy modrzewia rodzimego pochodzenia w świętokrzyskich lasach rządowych w pierwszej połowie XIX wieku. Acta Agraria et Silvestria series Silvestris 10: 5-38.

Białobok S (1986) Modrzewie Larix Mill. Nasze Drzewa Leśne. Monografie Popularnonaukowe. Volumin 6. PWN, Warszawa-Poznań.

Bornebusch CH (1948) Doświadczenia z modrzewiem polskim w Danii. Sylwan 92: 14-21.

Chapuis MP \& Estoup A (2007) Microsatellite null alleles and estimation of population differentiation. Molecular Biology and Evolution 24: 621631. doi:10.1093/molbev/msl191.

Chybicki IJ \& Burczyk J (2009) Simultaneous estimation of null alleles and inbreeding coefficients. Journal of Heredity 100: 106-113. doi:10.1093/ jhered/esn088. 
Do C, Waples RS, Peel D, Macbeth GM, Tillett BJ \& Ovenden JR (2014) NeEstimator v2: re-implementation of software for the estimation of contemporary effective population size $\left(\mathrm{N}_{\mathrm{e}}\right)$ from genetic data. Molecular Ecology Resources. 14: 209-214. doi:10.1111/1755-0998.12157.

Dostálek J, Frantík T, Pospíšková M \& Kř́ižová K (2018) Population genetic structure and delineation of conservation units in European larch (Larix decidua Mill.) across its native range. Flora 246247: 26-32. doi:10.1016/j.flora.2018.06.007.

Frankham R (1995) Effective population size/ adult population size ratios in wildlife: a review. Genetic Resources 66: 95-107. doi:10.1017/ S0016672300034455.

Goudet J (2001) FSTAT, a program to estimate and test gene diversities and fixation indices, Version 2.9.3. http://www2.unil.ch/popgen/softwares/ fstat.htm.

Gramazio P, Plesa IM, Truta AM, Sestras A, Vilanova $S$, Plazas M, Vicente O, Bosaciu M, Prohens J \& Sestras RE (2018) Highly informative SSR genotyping reveals genetic diversity and limited differentation in European larch (Larix decidua) populations from Romania. Turkish Journal Agriculture and Forestry 42: 165-175. doi:10.3906/ tar-1801-41.

Hampe A \& Petit RJ (2005) Conserving biodiversity under climate change: the rear edge matters. Ecology Letter 8: 461-467. doi:10.1111/j.14610248.2005.00739.x.

Hamrick JL, Godt MJW \& Sherman-Broyles SL (1992) Factors influencing levels of genetic diversity in woody plant species. New Forests 6: 95-124. doi:10.1007/978-94-011-2815-5 7.

Hardy OJ \& Vekemans X (2002) SPAGeDi: a versatile computer program to analyse spatial genetic structure at the individual or population levels. Molecular Ecology Notes 2: 618-620. doi:10.1046/j.1471-8278 .2002.00305.x.

Hardy OJ, Charbonnel N, Fréville H \& Heuertz M (2003) Microsatellite allele sizes: a simple test to assess their significance on genetic differentiation. Genetics 163: 1467-1482. PMCID: PMC1462522.

Isoda K \& Watanabe A (2006) Isolation and characterization of microsatellite loci from Larix kaempferi. Molecular Ecology 6: 664-666. doi:10.1111/ j.1471-8286.2006.01291.x.

Jalas J \& Suominen J (1973) Atlas Florae Europaeae: distribution of vascular plants in Europe Vol. 2 Gymnospermae (Pinaceae to Ephedraceae). The committee for Mapping the Flora of Europe and Societas Biologica Fennica, Vanamo, Helsinki.

Jansen S \& Geburek T (2016) Historic translocations of European larch (Larix decidua Mill.) genetic resources across Europe - A review from the 17th until the mid-20th century. Forest Ecology and
Management 379: 114-123. doi:10.1016/j.foreco.2016.08.007.

Jansen S, Heino K \& Geburek T (2017) The extent of historic translocation of Norway spruce forest reproductive material in Europe. Annals of Forest Science 74: 56 doi:10.1007/s13595-017-0644-z.

Jump AS \& Peñuelas J (2006) Genetic effects of chronic habitat fragmentation in a wind pollinated tree. Proceeding of the National Academy of Sciences 103: 8096-8100. doi:10.3732/ajb.0900148.

Jump AS \& Peñuelas J (2007) Extensive spatial genetic structure revealed by AFLP but not SSR molecular markers in the wind-pollinated tree, Fagus sylvatica. Molecular Ecology 16: 925-936. doi:10.1111/j.1365-294X.2006.03203.x.

Kocięcki S (1962) Modrzew polski w uprawach doświadczalnych. Sylwan 106: 23-34.

Lewandowski A \& Mejnartowicz L (1991) Levels and patterns of allozyme variation in some European larch (Larix decidua) populations. Hereditas 115: 221-226. doi:10.1111/j.1601-5223.1992. tb00565.x.

Lewandowski A (1995) Modrzew polski (Larix decidua subsp. polonica (Racib.) Domin) - struktura genetyczna populacji oraz jego pochodzenie w świetle badań izoenzymowych. Plantpress, Kraków.

Lewandowski A \& Burczyk J (2000) Mating system and genetic diversity in natural populations of European larch (Larix decidua) and stone pine (Pinus cembra) located at higher elevations. Silvae Genetica 49: 158-161.

Lewandowski A, Szydlarski M \& Litkowiec M (2014) Origin of Norway Spruce (Picea abies (L.) Karst.) in the Kartuzy Forest District. Sylwan 158: 509515.

Litkowiec M, Lewandowski A \& Wachowiak W (2018) Genetic variation in Taxus baccata L.: a case study supporting Poland's protection and restoration program. Forest Ecology and Management 409: 148-160. doi:10.1016/j.foreco.2017.11.026.

Loiselle BA, Sork VL, Nason J \& Graham C (1995) Spatial genetic structure of a tropical understory shrub, Psychotria officinalis (Rubiaceae). American Journal of Botany 82: 1420-1425. doi: $10.2307 / 2445869$.

Maier J (1992) Genetic variation in European larch (Larix decidua Mill.). Annals of Forest Science 49: 39-47. doi:10.1051/forest:19920104.

Matras J \& P ques L (2008) Euforgen technical guidelines for genetic conservation and use for European larch (Larix decidua). Bioversity International, Rome, Italy.

Mosca E, Eckert AJ, Di Pierro EA, Rcchini D, La Porta N, Belletti P \& Neale DB (2012) The geographical and environmental determinations of genetic diversity four alpine conifers of the European Alps. 
Molecular Ecology 21: 5530-5545. doi:10.1111/ mec.12043.

Mosca E, González-Martínez SC \& Neale DB (2014) Environmental versus geographical determinants of genetic structure in two subalpine conifers. New Phytologist 201: 180-192. doi:10.1111/ nph.12476.

Münch E (1936) Das Lärchensterben. Forstwissenschaftliches Zentralblatt 58: 641-671.

Myking T, Rusanen M, Steffenren A, Kjær ED \& Jansson G (2016) Historic transfer of forest reproductive material in Nordic region: drivers, scale and implications. Forestry 89: 325-337. doi:10.1093/ forestry/cpw020.

Nardin M, Musch B, Rousselle Y, Guérin V, Sanchez L, Rossi JP, Gerber S, Marin S Pâques L \& Rozenberg P (2015) Genetic differentiation of Eurpean larch along an altitudinal gradient in the French Alps. Annals of Forest Science 72: 517-527. doi:10.1007/s13595-015-0483-8.

Nybom H (2004) Comparison of different nuclear DNA markers for estimating intraspecific genetic diversity in plants. Molecular Ecology 13: 1143 1155. doi:10.1111/j.1365-294X.2004.02141.x.

Paffetti D, Travaglini D, Buonamici A, Nocentini S, Vendramin GG, Giannini R \& Vettori C (2012) The influence of forest management on beech ( $\mathrm{Fa}$ gus sylvatica L.) stand structure and genetic diversity. Forest Ecology and Management 284: 34-44. doi:10.1016/j.foreco.2012.07.026.

Pâques LE, Sylvestre Guinot G \& Delatour C (1999) Variabilité clonale de la race polonica du mélèze d'Europe pour la résistance à Lachnellula willkommii. Annales des Sciences Forestieres 56: 155166. doi:10.1051/forest:19990207.

Pâques LE, Foffová E, Heinze B, Lelu-Walter MA, Liesebach M \& Philippe G (2013) Larches (Larix sp.): Forest tree breeding in Europe (ed. by LE Pâques) Springer, Netherlands, pp. 13-122. doi:10.1007/978-94-007-6146-9 2.

Peakall R \& Smouse PE (2006) GENALEX 6: genetic analysis in Excel. Population genetic software for teaching and research. Molecular Ecology Notes 6: 288-295. doi:10.1111/j.14718286.2005.01155.x.

Petit JR \& Hampe A (2006) Some evolutionary consequences of being a tree. Annual Review of Ecology, Evolution and Systematics 37: 187-214. doi:10.1146/annurev.ecolsys.37.091305.110215.

Pluess AR (2011) Pursuing glacier retreat: genetic structure of a rapidly expanding Larix decidua population. Molecular Ecology 20: 473-485. doi:10.1111/j.1365-294X.2010.04972.x.
Pritchard JK, Stephens M \& Donnelly P (2000) Inference of population structure using multilocus genotype data. Genetics 155: 945-959. doi:10.1111/j.1471-8286.2007.01758.x.

Raciborski M (1890) Kilka słów o modrzewiu w Polsce. Kosmos 15: 488-497.

Raymond M \& Rousset F (1995) An exact test for population differentiation. Evolution 49: 12801283. doi:10.2307/2410454.

Robledo-Arnuncio JJ, Alía R \& Gil L (2004) Increased selfing and correlated paternity in small population of a predominantly outcrossing conifer, $\mathrm{Pi}$ nus sylvestris. Molecular Ecology 13: 2567-2577. doi:10.1111/j.1365-294X.2004.02251.x.

Rousset F (2008) genepop'007: a complete re-implementation of the genepop software for Windows and Linux. Molecular Ecology Resources 8: 103106. doi:10.1111/j.1471-8286.2007.01931.x.

Rożkowski R, Chmura DJ, Chałupka W \& Guzicka M (2011) Growth and quality traits of half-sib progeny of Polish larch (Larix decidua subsp. polonica (Racib.) Domin) from Góra Chełmowa during 37 years of growth. Sylwan 155: 599-609.

Sokal RR \& Rohlf FJ (1995) Biometry: The principles and practice of statistics in biological research. 3rd ed. W.H. Freeman and Co., New York.

Szafer W (1923) Z prac doświadczalni leśnych w Szwajcarii. Sylwan 41: 69-75.

Wagner S, Gerber S \& Petit RJ (2012) Two highly informative dinucleotide SSR multiplexes for the conifer Larix decidua (European larch). Molecular Ecology Resources 12: 717-725. doi:10.1111/ j.1755-0998.2012.03139.x.

Wagner S, Liepelt S, Gerber S \& Petit RJ (2015) Within-range translocations and their consequences in European larch. PloSone 10: e0127516. doi:10.1371/journal.pone.0127516.

Weisgerber H \& Šindelăř J (1992) IUFRO`s role in coniferous tree improvement. History, results and future trends of research and international cooperation with European larch (Larix decidua Mill.). Silvae Genetica 41: 150-161.

Wójkiewicz B, Litkowiec M \& Wachowiak W (2016) Contrasting patterns of genetic variation in core and peripheral populations of highly outcrossing and wind pollinated forest tree species. AoB Plants plw054. doi:10.1093/aobpla/plw054.

Vekemans X \& Hardy OJ (2004) New insight from fine-scale spatial genetic structure analyses in plant populations. Molecular Ecology 13: 921935. doi:10.1046/j.1365-294X.2004.02076.x 